\title{
Opportunities and Challenges for Producing Solar Energy in Every Indian Home - A Case Study
}

\author{
P. Sridhar Acharya, ${ }^{1} \&$ P. S. Aithal ${ }^{2}$ \\ 1, 2 Srinivas Institute of Management Studies, Srinivas University, Mangalore - 575 001, \\ INDIA. \\ E-Mail: sridharaacharya@gmail.com
}

Type of the Paper: Case Study.

Type of Review: Peer Reviewed.

Indexed In: OpenAIRE

DOI: http://dx.doi.org/10.5281/zenodo.1133921.

Google Scholar Citation: IJCSBE

\section{How to Cite this Paper:}

Acharya Sridhara P, \& Aithal, P. S. (2017). Opportunities and Challenges for Producing Solar Energy In Every Indian Home - A Case Study. International Journal of Case Studies in Business, IT and Education (IJCSBE), 1(2), 114-119.

DOI: http://dx.doi.org/10.5281/zenodo.1133921.

International Journal of Case Studies in Business, IT and Education (IJCSBE)

A Refereed International Journal of Srinivas University, India.

(C) With Authors.

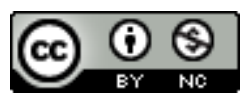

This work is licensed under a Creative Commons Attribution-Non Commercial 4.0 International License subject to proper citation to the publication source of the work.

Disclaimer: The scholarly papers as reviewed and published by the Srinivas Publications (S.P.), India are the views and opinions of their respective authors and are not the views or opinions of the S.P. The S.P. disclaims of any harm or loss caused due to the published content to any party. 


\title{
Opportunities and Challenges for Producing Solar Energy in Every Indian Home - A Case Study
}

\author{
P. Sridhar Acharya, ${ }^{1} \&$ P. S. Aithal ${ }^{2}$ \\ 1, 2 Srinivas Institute of Management Studies, Srinivas University, Mangalore - 575 001, \\ INDIA. \\ E-Mail: sridharaacharya@gmail.com
}

\begin{abstract}
The energy from the sun is abundant for essential requirements of every home. But due to technological reasons, it is not so easy to use the solar energy by converting it into electrical energy efficiently in all places. The important factors which would be affecting the efficiency of the solar panels (which is presently in the range of $20 \%$ to $30 \%$,) are the cost involved in implementing the same at each house, lack of knowledge on investment return etc. The semiconductor technology for fabricating solar cells contributes to the performance. The impurities in the semiconductor technology, the heat from the sunlight are the negative factors for the performance. The variation in the angle of sunlight incident from morning to evening is also a negative factor for the performance. The climate condition of the environment like cloudy weather which limits the sunlight falling into the panel is another limiting factor. Considering all these limiting factors this paper proposes the different modes of installation of solar energy. This paper contains the normal power requirement of the house and methods for either partial or complete solar energy installation to the individual house.
\end{abstract}

Keywords: Solar energy, Panel efficiency, Semiconductor technology, Case study.

\section{INTRODUCTION :}

The electrical energy is available to the home using nonrenewable energy resources such as hydroelectricity, electricity from thermal energy, atomic energy and so on. The problem in this nonrenewable energy is the supply and demand ratio is always not 1:1. The demand is much more than the supply. The government is trying level best to meet the demand of the electricity needs. Such energy produced from the nonrenewable resource is contributing a large amount of pollution in the form of $\mathrm{CO}_{2}$, toxic gases, and water pollution. This is another challenge for the government to minimize the environmental pollution from the non-renewable energy resources. So the scarcity of the energy produced using non-renewable energy and its pollution made the government to seriously think about the energy from the renewable resources.

The government of India started working on the renewable energy under the ministry of nonconventional energy during the 1980s. Our country is the first to establish a ministry on this renewable energy management under the banner of nonconventional energy [1]. Today our country is in a position to get the power of $57.472 \mathrm{GW}$ as of 14 June 2017 [2]. The contribution of energy from wind is $61 \%$ whereas from solar energy is only $19 \%$. Looking into the efficiency of the renewable energy resources wind energy is more efficient than solar energy [3]. But wind energy system cannot be implemented to individual houses as the requirements to establish the wind energy are :

- The speed of the wind should be minimum $20 \mathrm{Km}$ per hour.

- Longer the blades larger will be the energy production.

- Cost of initial investment is too heavy.

- The area surrounded by the wind energy should be free from obstacles.

However smaller wind turbines of the range 400Watts to 20KiloWatts are available for individual houses. The problem in installing such wind turbines in the individual houses is due to the lack of wind blow to generate the energy. This is also due to the non-availability of the free space around the house. Due to this the wind blow will not be possible due to various obstacles from the neighboring buildings or packed structure of houses or apartments. All these are negative aspects to generate 
energy through the wind turbines [4]. The wind energy can generate energy 24 hours a day whenever there is enough amount of wind blow is there. Even though the efficiency of wind turbine both in commercial scale and small scale is $60 \%$ it is not getting entertained by individual houses for decentralized production because the initial cost is too high, irregular wind blow and regular maintenance work is difficult.

Even though the efficiency of solar energy is just $18 \%$ due to several factors the solar energy system is more entertained in individual houses as a decentralized energy source. The factors are

- Availability of convenient power generation.

- The rooftop is large enough to install the solar panel.

- In all the houses the sunlight is available at least for five to six hours [5].

The solar panel will be available in different sizes and different power ratings. This makes the owner to decide what is the capacity of the power production, what is the area of the rooftop which is suitable for installing the solar panel and what is the cost of installation [6].

It is very clear from the above introduction that instead of going for a small scale wind energy even though the efficiency of the same is $60 \%$, due to the geographical structure of the house which blocks the wind blow thus it is not advisable to have a decentralized wind turbine at each house.

\section{OBJECTIVES :}

The objective of this paper is to design a model which can realize the implementation of solar energy to the individual house and to study the benefits after implementation. To propose the model it is necessary to identify the design and the structure of the house, the electrical needs, and the cost of implementation.

\section{METHODOLOGY :}

The model is proposed after the study of the following factors

- The nature of the house

- The total area which needs electrification

- Complete or partial electrification

Diagrammatically the model can be represented as shown in figure 1.

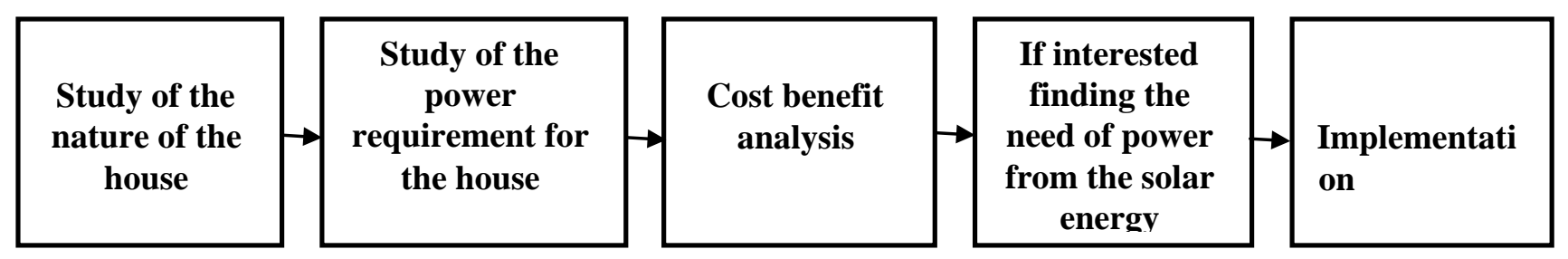

Figure 1: The proposed model for installing the solar energy at individual sample house.

The sample house can be either independent house or a house in an apartment. The average living space of a hose will be around 1100 Sq feet. The table 1 shown below explains the daily household equipment in an independent as well as a house in a flat having 2 bedrooms and one living room with kitchen and toilets.

Table 1 : Daily electrical load in the sample house

\begin{tabular}{|l|l|l|l|l|l|}
\hline S. No. & Appliance & $\begin{array}{l}\text { Power in } \\
\text { Watts }\end{array}$ & $\begin{array}{l}\text { Total Number } \\
\text { of Appliance }\end{array}$ & $\begin{array}{l}\text { Number of } \\
\text { Hours Used }\end{array}$ & Total Power \\
\hline 1. & Light (LED) & $20 \mathrm{~W}$ & 15 & 5 & $1,500 \mathrm{~W}$ \\
\hline 2. & Fans & $75 \mathrm{~W}$ & 5 & 7 (Average) & $2,625 \mathrm{~W}$ \\
\hline 3. & TV (52 inch LED) & $50 \mathrm{~W}$ & 1 & 10 & $500 \mathrm{~W}$ \\
\hline 4. & Refrigerator & $400 \mathrm{~W}$ & 1 & 5 & $2,000 \mathrm{~W}$ \\
\hline 5. & Iron Box & $800 \mathrm{~W}$ & 1 & 1 & $800 \mathrm{~W}$ \\
\hline 6. & Washing Machine & $600 \mathrm{~W}$ & 1 & 2 & $1,200 \mathrm{~W}$ \\
\hline
\end{tabular}


From the Table 1, it is clear that a normal two bedded house is consuming almost 8.6 units of power per day. Out of the above domestic appliances Refrigerator, Iron Box and Washing machine can be considered as heavy electric consuming appliances and they need not be under solar electrification. Excluding the above equipment if we get the energy from solar the items to be installed at home are as shown in table 2.

Table 2: Solar Equipment with the quantity and the price

\begin{tabular}{|l|l|l|l|}
\hline S. No & Item & Quantity & Price in Rs \\
\hline 1. & Solar Panel & $1,500 \mathrm{~W}$ (150W X 10) & 75,000 \\
\hline 2. & UPS system-2KVA & 1 & 25,000 \\
\hline 3. & Battery Backup & 4 & 60,000 \\
\hline \multicolumn{2}{|l|}{ Total Investment } & $1,60,000$ \\
\hline
\end{tabular}

In order to get electricity from solar to produce 4 units $(4 \mathrm{KW})$ per day one has to spend Rs 160000 toward solar energy system. It is clear that the major cost factors are the panel cost and the backup battery cost. The cost recovery is calculated as follows

Total amount of power produced in a year $=4$ X 30 X 9 months (excluding rainy season)

Cost per unit

Number of years required to recover

The lifespan of the solar system is as shown below

Life span of Solar panel

Life span of the UPS system

Life span of Battery

$$
1,080 \text { Units }
$$

$=$ Rs 6,480 per year

$$
=25 \text { years }
$$

$=25$ years

$=10$ years

$=6$ years

If partial electricity requirement is fulfilled using solar energy only for lighting system then the power requirements will be reduced to just $1500 \mathrm{~W}$ Then the requirements of solar equipment will be as shown in table 3.

Table 3: Solar Equipment with the quantity and the price

\begin{tabular}{|l|l|l|l|}
\hline S. No & Item & Quantity & Price in Rs \\
\hline 1. & Solar Panel & $500 \mathrm{~W}$ & 25000 \\
\hline 2. & Charge Control & 1 & 3000 \\
\hline 3. & Battery Backup & 1 & 10000 \\
\hline \multicolumn{2}{|l}{ Total Investment } & 38000 \\
\hline
\end{tabular}

The above model is good only for the independent house and not for the apartments. A separate model may be suggested for the apartments where a common rooftop must be used for the installation of the solar panels and the separate backup facility common for all the apartments. This model suggests all the apartments to use solar energy for common area and lighting system only since the complete electrification becomes costly and regular maintenance may not be as easy as every member of the apartment is responsible for the maintenance. Here depending on the opinion of residents expansion to individual apartments is also possible. The model as discussed in table 3 may be suggested for the apartment systems.

\section{ANALYSIS :}

The energy from solar PV panel is sufficient to fulfill the electrical needs of the individual house. The area required for installation of the solar panel at the roof which is large enough to provide the electrical needs. Solar PV panel can produce a power of $1 \mathrm{KW}$ in $5.56 \mathrm{~m}^{2}$ area having its face towards the south in India. 1000 Watts = Total Area $\times 1000$ Watts $/ \mathrm{m}^{2}$ x 0.18 where 0.18 is $18 \%$ efficiency of 
the solar panel. The additional benefit of fixing solar panels on the roof is to bring down the temperature of the living area as the sunlight directly hits the panel and energy conversion takes place instead of heat.

\subsection{Advantages :}

Having a complete solar electric system for the house has several advantages like :

1. All the time you will be getting electrical energy.

2. Use of renewable energy reduces the pollution.

3. There is no scarcity of sunlight as we have in conventional methods where we do have a scarcity of coal, uranium, and water.

4. Convenient in deciding the required energy generation.

\subsection{Benefits}

Using solar energy at home has the following benefits

- Independent energy system

- No connection with the conventional electricity providers

- No need for monthly bill payments to the Electricity supplier board.

\subsection{Constraints}

Implementation of the Solar system has the following constraints

- Initial investment is costly.

- Regular maintenance of battery backup.

- Lifespan of battery and UPS are not certain.

- The lifespan of the solar panel is 25 years and almost 26 years are required for the recovery of the investment if no other maintenance is required.

\subsection{Drawbacks}

The model mentioned above has the drawbacks

- Costly.

- Climate condition which results in irregular production.

- Regular maintenance.

- Lack of knowledge

\section{CONCLUSION :}

Having a solar energy system in the individual house is going to be the next trend. Now the government is entertaining people to have a solar system in their house. The government has to plan for reducing the cost of panels and battery backups as the major cost consuming items are these two. Awareness of using the solar energy is needed for popularizing the solar energy system. This reduces the supply-demand ratio which is not equal to 1:1.

\section{LIMITATIONS OF THIS STUDY :}

This study has following limitations

- The energy need differs from house to house hence it is not possible to generalize the power consumption to all the houses as mentioned in the table. Some houses may consume less energy and others may consume more energy depending on electrical appliances used.

- The geographical location of the house is one factor which changes the efficiency of the solar panel. This is one reason where the efficiency changes in between 20 to $30 \%$. This variation in the efficiency changes the number of panels to be installed from place to place and hence the expenditure.

- The cost and the lifetime of the panel cannot be predicted because the cost is varying from day to day and the lifespan of the panel depends on the backup systems, load balancing, maintenance etc.

- The batteries are additional limiting factors. The cost of the battery changes from time to time. The lifespan of the battery depends on the geographical location, general maintenance, load balancing etc. 


\section{REFERENCES:}

[1] Karan Kapoor, Krishan K. Pandey, A.K. Jain, Ashish Nandan. (2014). Evolution of solar energy in India: A review. Renewable and Sustainable Energy Reviews. 40, 475-487.

[2] Al-Addous M., Dalala Z., Class C.B., Alawneh F., Al-Taani H. (2017). Performance analysis of off-grid PV systems in the Jordan Valley. Renewable Energy, 113, 930-941. DOI : https://doi.org/10.1016/j.renene.2017.06.034.

[3] Gassemi Abbas, Nelson Vaughn. (2013). WIND ENERGY Renewable Energy Environment. Second Edition CRC Press. ISBN 13:978-1-4665-8161-6. pp. 45-62.

[4] Tian Pau Chang. (2011). Estimation of wind energy potential using different probability density functions. $\quad$ Applied Energy, 88(5), 1848-1856. DOI : https://doi.org/10.1016/j.apenergy.2010.11.010.

[5] Acharya Sridhara, P. \& Aithal, P. S. (2015). Innovation in Effective Management of Energy using Green Technology. International Journal of Conceptions on Management and Social Sciences, 3(2). 18 - 22, DOI : http://doi.org/10.5281/zenodo.268814.

[6] Acharya Sridhara, P. \& Aithal, P S. (2017). Increasing the Efficiency in Renewable EnergyChallenges and Solutions for Rural India. International Journal of Applied Engineering and Management Letters (IJAEML). 1(1), 1-5. DOI: http://dx.doi.org/10.5281/zenodo.810341. 